\title{
ENCOURAGING EMPLOYEE'S INTRAPRENEURSHIP HABIT TO REDUCE CORRUPTION
}

\author{
Slamet Wahyudi \\ Dosen Program Studi Sekretari (Administrasi Bisnis), Politeknik Ubaya, Surabaya \\ Email: slamet.wahyudi@staff.ubaya.ac.id
}

\begin{abstract}
Indonesia recently ranked 96th for corruption index from 180 countries, means that still a lot of effort needed to reduce the number. The Imposing of laws for those who commit corruption and bribery have been implemented. Moreover, Government and Schools though people and student how to prevent it. Corruption becomes the main topic in everyday news. This paper tries to propose another action in order to reduce it namely Intrapreneurship. Intrapreneurship is similar to entrepreneurship, the first term refer to employees develops new business ideas for their companies within the company. On the other hand, Entrepreneurships defines as someone who starts up a new business with creativity to gain profit for better living using their own resources. This paper with design thinking method aims to find out some strategies how company could implement this program and at the end could reduce corruption.
\end{abstract}

Keywords: , Entrepreneurship, Employee’s Habit, Corruption, Design Thinking.

\section{Introduction}

Indonesian employees in general receive inadequate salary per month, around IDR 3 Millions or depend on the area of the company and types. On the other hand, cost of living increase gradually this year, IDR or Indonesian rupiah weaken and is predicted to fall again by the end of the year. Corruption is far impossible for employees who could gain more sources of incomes; at home he can do business using his own resources. In addition at the office he or she could develop new business unit, product or ideas and help the company to receive more profits. For instance, if the company suffers from sales declining, as an active member of the company, he or she could offer new strategy how to boost selling again. This effort might works, then as the consequences, company must give this particular employee additional money as a reward for his excellent works. The company must encourage intrapreneurship habit in many areas, certainly one example is not enough; company needs a strategy to spread out this idea in all management level. This paper aims to find out some strategies how company could implement this program and at the end could reduce corruption. 
Various efforts have been imposed by the Government to reduce the domino effect of corruption. Ranging from the movement of the Corruption Eradication Commission (KPK) to catch many big cases in the Governmental institution, followed by others strict laws proposed by the government to mitigate massive corruption. However, it keeps going and growing in many areas not only in the governmental sector but also in many private business and companies.

Those who commit corruption could be categorized as a person who needs more source of incomes to fulfill his/her needs and wants. If only they have another way of getting money, there is a chance we could reduce corruption, fraud and others gradually. Indonesia is the 96 least corrupt nations out of 175 countries in the world, this data taken was from the 2017 Corruption Perceptions Index. Indonesia ranked 100.09 from year 1995 up to 2017 as the most corrupt countries in the world, reached it peak as high of 143 in 2007 (tradingeconomic, 2018).

This paper aims to propose intrapreneurship habit and behavior as one way to get another source of income within the workplace legally. The term Intrapreneurship is similar to what we have known as entrepreneurship. On one hand, entrepreneur defined as someone with all his creativity and ideas creating a new business line to gain income using his own resources (Parker, 2011). On the other hand, intrapreneurship refers to someone within company or organization that has idea to create new business unit to increase company's profit (Parker, 2011). While entrepreneurship is a common term we easily find in daily business conversation, intrapreneurship still relatively new business term.

Despite the massive research on entrepreneurship in Indonesia lately, we still lack of effort to create a specific work about Intrapreneurship. As explained in one of a research, Intrapreneurship is widely known in the more developed nation compared to the less developed nation (Antoncic \& Hisrich, 2001). In addition, companies in country like USA and French already familiar with the Intrapreneurship concept; therefore the leader of the company could apply some strategies to encourage employee's intrapreneurship habit for the sake of the company and employees themselves at the end (Antoncic \& Hisrich, 2001). Intrapreneurship is beneficial both for SME (small medium enterprise) and moreover for the bigger company.

According to Antoncic \& Hisrich (2001), Intrapreneurship has four dimensions, which are including new business venturing dimension, innovativeness dimension, self-renewal dimension and the last is pro-activeness dimension. Intrapreneurship refers to not only new business venture, but also to some innovative and creative activities, including product and service development, application of proper technologies, better administrative techniques, and strategies improvement to win business competition (Antoncic \& Hisrich, 2001). Based on that definition, Intrapreneurship could be called as entrepreneurship within the organization. There is no prove yet, if this concept suits to Indonesian companies, the top down managerial system, very centralized command and less encouragement for employees to involve in some potential improvement have been make it difficult to implement it here in Indonesia. Having said that, while globalization continue massively, that influence Indonesian leader to adopt more modern concept like in the more developed nation, as a consequence, Intrapreneuership believes to be one of company's consideration in the near future.

In research paper of Rojuaniah, et al. (2016) there are eight factors that could trigger employees to have solid Intrapreneurship habit and behavior. These are leadership, remuneration, organization culture, openness degree of communication, workplace, career path development, technology and personal traits. 
In fact, there are many MNC (multinational company) operates in Indonesia; these companies gradually bring Intrapreneurship habitual into Indonesia indeed. This phenomenon becomes a main topic in other area apart from business, for instance in educational industry. The rector of UII on one occasion told that, university also must encourage Intrapreneur habits in order to excel in the competition (UII, 2017).

Based on the description earlier, the main focus of this paper is drawn: How to encourage employees to have intrapreneurship habit in order to reduce corruption?

\section{Research Method}

Since this is a basic research, and the purpose is to find the strategy how to encourage employees aware and keen on intrapreneurship, we choose design thinking method. Design thinking is a more qualitative method. Design a new think with asking interviewees some questions and explore their ideas deeply about the topics (IDEO, 2015). Design thinking consists of Empathize phase, define, ideate, prototype and lastly test the prototype phase (Margiono, 2011).

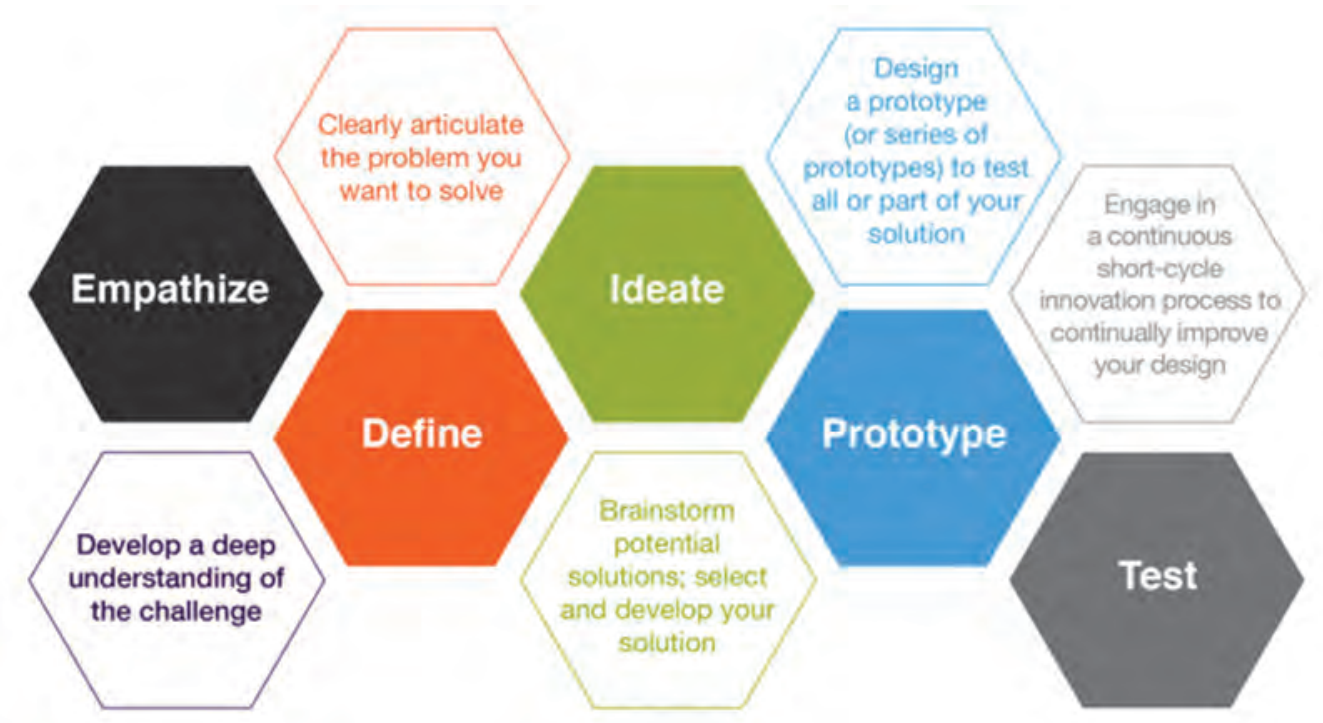

Source: https://esqbs.ac.id/viewed 13 March 2018

\section{Result and Discussion}

\section{a. Empathize}

We did survey and deep interview to various different groups of respondent mostly are employees, managers and business owners. This Empathize stage allows researcher to set aside assumptions about the development of Intrapreneurship In Indonesia in order to gain insight and exact needs. Some crucial information gathered to build best possible understanding of the users and then to use during next stage. Here are some important data we have collected.

$47,7 \%$ of the respondents agrees with the Intrapreneurship purposes in encouraging creativity and innovation of employees. While very few who disagree. 
1) Apakah anda setuju dengan konsep Intrapreneurship?

S9 tanogapan

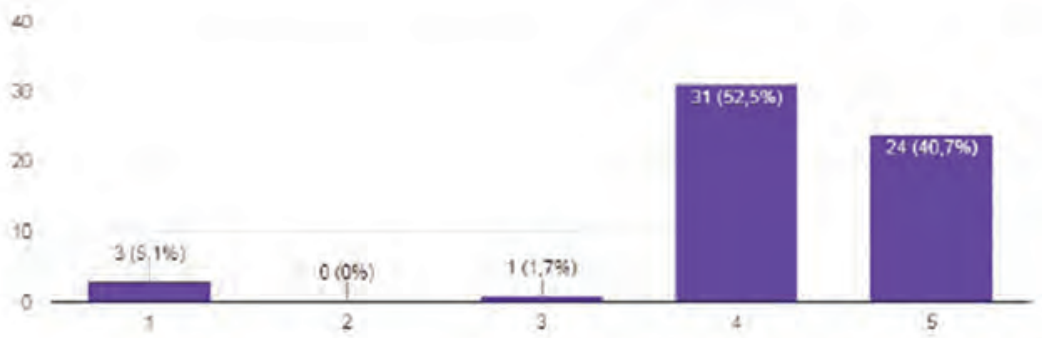

2) Apakah Intrapreneurship penting untuk perusahaan di negara berkembang?

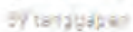

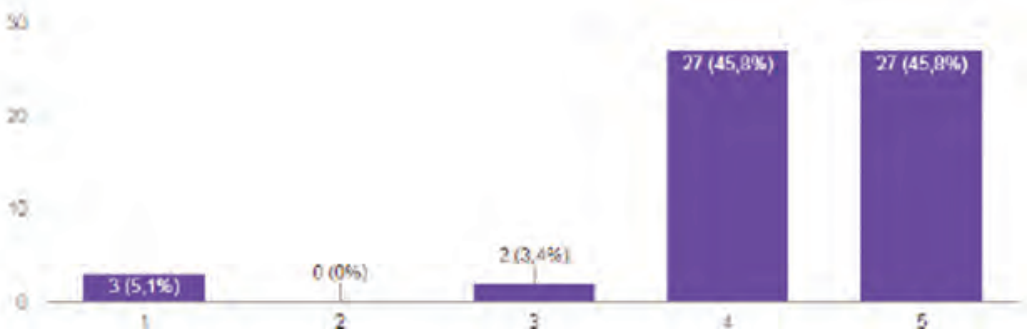

3) Apakah Intrapreneurship bisa diterapkan di Indonesia saat ini 55 rangyapan

30

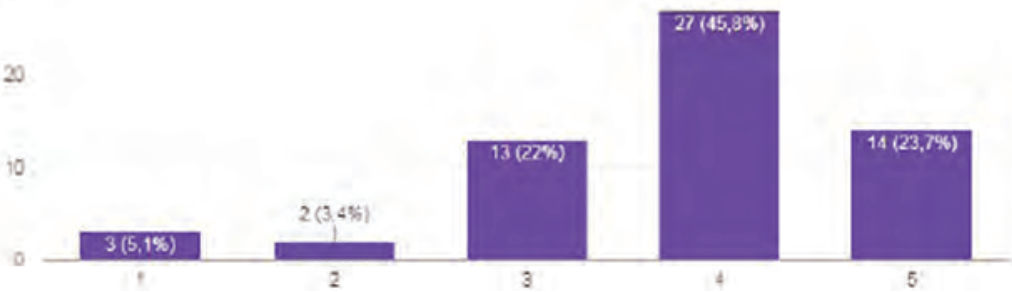

1) Apakah anda berminat untuk menjadi Intrapreneur?

3 ta 2030 al

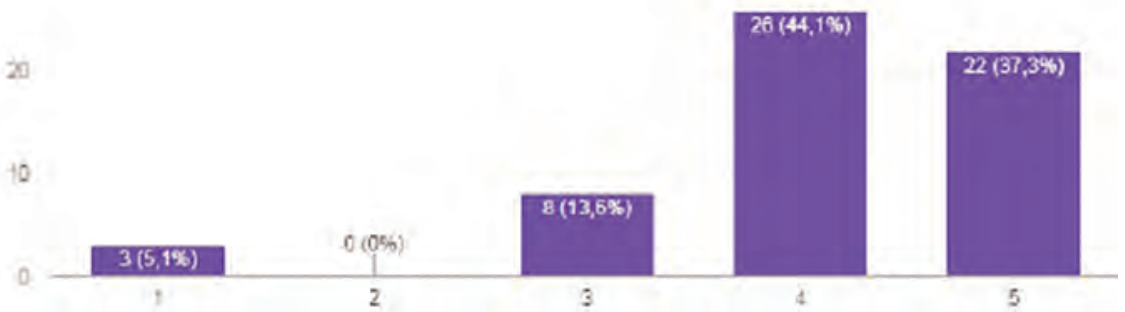




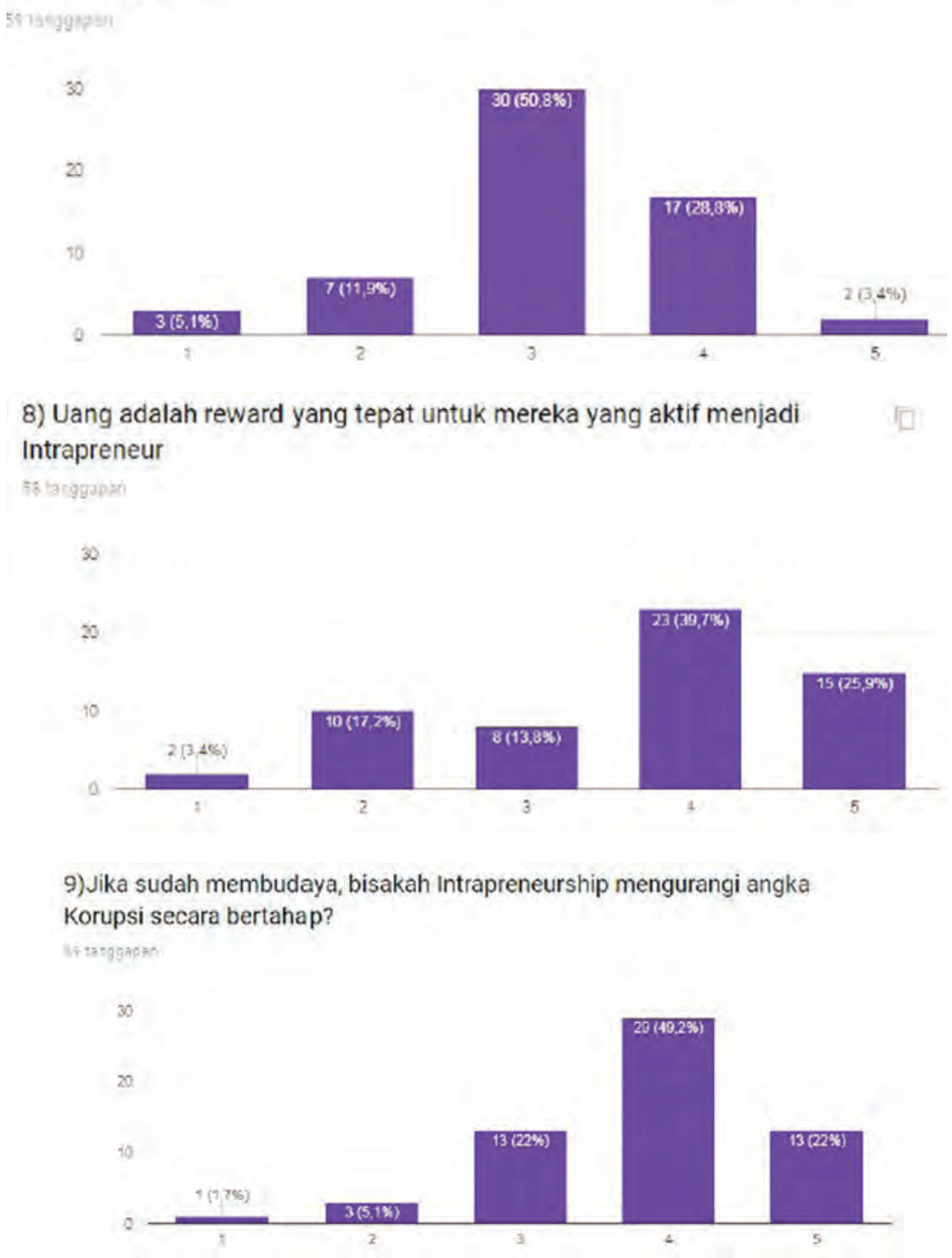

\section{B. Define}

After empathizing respondent and interviewees experience's regarding this idea, the second stage is defining. As we interact and got some beneficial human touch, then we can define by constructing respondents point of view based on their needs and wants. We will define problems related on field of Intrapreneurship and corruption. Defining and framing problem should be clear and unbiased based on the interaction with respondent we did before.

User, need and Insight are all three factor researchers need to consider in order to formulate an actionable problem definition on developing intrapreneurship to avoid corruption in Indonesia. These are some related ides we defined. Here, there are two types of Employees, first those 
individual who mainly seeking for salary only, secondly those who work in order to get salary and another additional income as achievement also. Their emphasized needs are a good salary plus another additional sources of income within the company.

Lastly, researchers get this Insight; preparing employees to take part or involve in company's program to promote Intrapreneurship. For instance, one of National Bank Indonesia like BTPN, with its excellent employees salary and benefit, in addition it has a program called employee get employee, this program encourages many employees to refer his/her friends to the HRD, as a result when one of his/her friend selected and then he will get reward in the form of money, well that's interesting indeed. Not to mention that many other internal contest like the best operation staff and marketing staff completion with very valuable prices also trigger employees to push their best and creativity to win price from the campaign. Another example is PT Matahari Department Store with its best employee of the month program, this program actually created to encourage employees to perform their best every day, best employee deserve to get fresh money for prize.

\section{Ideate}

Here, researcher try to provide both fuel and also all valuable sources and material to support many ideas from the earlier processes above. After all, the main purpose of this step is to create solution for some objectives we have in this research, which is encouraging Intrapreneurship to avoid or at least to reduce corruption habits among employees.

Based on the data we collected and some information from the respondent and interviewees, we come out with clear Idea in regard to this topic. On one hand, accordingly Indonesia has a sound potential to reduce the corruptions index and getting better appreciation from investors around Asia and the rest of the world due to its massive effort to fight against corruption. Indonesian Corruption Eradication Commission (KPK) work intensively and already proven it becomes a nightmare for those who commit corruption.

On the other hand, Indonesia's KPK needs to expand its work gradually into other area, nowadays only Jakarta as the capital city that KPK has their main office. But no representative exists yet in the other provinces.

Apart from KPK, almost all of school and university in Indonesia now are promoting good attitude and habits, they put Integrity as the main soft skill students should have. Ubaya Polytechnic in Surabaya for instance, really concern about students integrity, hence once they graduate and work either in Governmental or private sector they will become an employee that company can trust, will never commit corruption and bribery in any type hopefully.

KPK and Educational Sector have been working continuously to avoid and reduce corruption. However, news and information regarding numbers, case, types and people with corruption are very easy to find. That's mean corruption is a very serious matter for a developing nation like Indonesia.

Writer suggests another alternative solution in order to reduce corruption, which companies and organizations might be possible to do. Let's try promoting Intrapreneurship, if both employer and employee agree to implement this as their organizational habit and soon become culture, there is a hope that people will feel enough and secure in term of financial without committing corruption. This idea might be challenged by facts that corruption is already embedded severely and becomes common, however with millennial start to work and turn as employer and business owner or employees and workers, I have a faith that this is not a mission impossible to do. 


\section{Prototype}

Finally, design thinking is different type of a research because it has a part which called prototyping. In order to sum up the research, here writer offers possible prototypes as solution for this matter.

a. Start all this Idea with imposing a compulsory training on Intrapreneurship for new employees. By giving that program, both employer and employee will start to have a mutual understanding about Intrapreneurship, benefits, function, triggers and obstacles.

b. Secondly, after training, employers should promote some programs and calculate the budget related on Intrapreneurship programs. Some interesting and actionable program are;

i. Employees of the month/years

Employers collect data on employee's performance from various source of data, then rank them, employee with the best performance should be prized with sum amount of money to attract others giving their best at the workplaces.

ii. Ideas and creative competition

This competition could be held twice per year, the competition could vary from photograph contest up to writing contest related to their task at the office, the best masterpieces should be get prizes at the end of the competition.

iii. Employee get employee Usually HRD find it difficult to get a good employee for a specific task, one way to solve this is by asking current employee's referral, one employee may refer his/her friends to apply for the position. If his/her friend match the HRD requirement for the job then the current employee will get reward from the HRD in helping them to find the right man for the right job.

iv. Mystery Shopper marking

This program could be implement in order to promote employee's excellent service, mystery shopper could come from third parties people, who has no connection with the company but pretend to become a customer, while he meet the employees and ask for something related to the company's product and service, the mystery shopper will take note about the employees performance. The best employees will be decided based on the point gave by mystery shoppers.

c. A suitable province to start this could be Surabaya, with a good habit of the local government leader, Surabaya with many industry reside here. The local government could promote this idea by inviting all the industry leaders to discuss about this and kick off the program.

\section{E. Test}

This step is a crucial and yet very challenging phase, however it requires further action, therefore we initiate to do additional research in this topic and test prototypes to users we have earlier and others related parties.

\section{Conclusion}

Based on the description above, it can be concluded that in the process of promoting intrapreneurship to reduce corruption, local government and companies should synergize and create some interesting program. Some programs state above earlier should be test before implementation. If KPK work for so many big cases in the government sectors, school and university teach entrepreneurship, then it should be very meaningful effort if all employers or 
company's owner, directors, managers start to implement this idea, we will experience a gradual decrease of corruption in the future.

\section{References}

Antoncic, Bostjan., Hisrich D. Robert., 2001. Intrapreneurship: Construct refinement and cross cultural validation. Journal of Business Venturing, Elsevier Science Inc.

Esqbs., 2018. Model Design Thinking. https://esqbs.ac.id/ viewed 13 March 2018

Ideo., 2015. The Field Guide to Human-Centered Design. $1^{\text {st }}$ Edition, ISBN: 978-0-9914063-1-9: Canada

Margiono A, M., 2011. Menuai Inovasi Lewat Design Thinking. Edisi minggu Bisnis Indonesia www.bisnis.com

Parker C. Simon., 2011. Intrapreneurship or Entrepreneurship. Journal of Business Venturing

Rojuaniah, Sule T Ernie, Joeliaty, Sutisna., 2016. The Factors influence Intrapreneurship Behavior in Construction Company. International Journal of Scientific \& Technology Research.

Tradingeconomic., 2018. Corruption Rank 2018. https://tradingeconomics.com/indonesia/ corruption-rank

UII, 2017. Pidato Rektor, www.uii.ac.id 